Dept. of Animal and Poultry Production,

Fac. of Agric., Univ. of Assiut, Egypt.

\title{
PRODUCTIVE AND REPRODUCTIVE PERFORMANCE OF JAPANESE QUAIL AS AFFECTED BY TIME OF FEED IN HOT CLIMATE
}

(With 8 Tables)

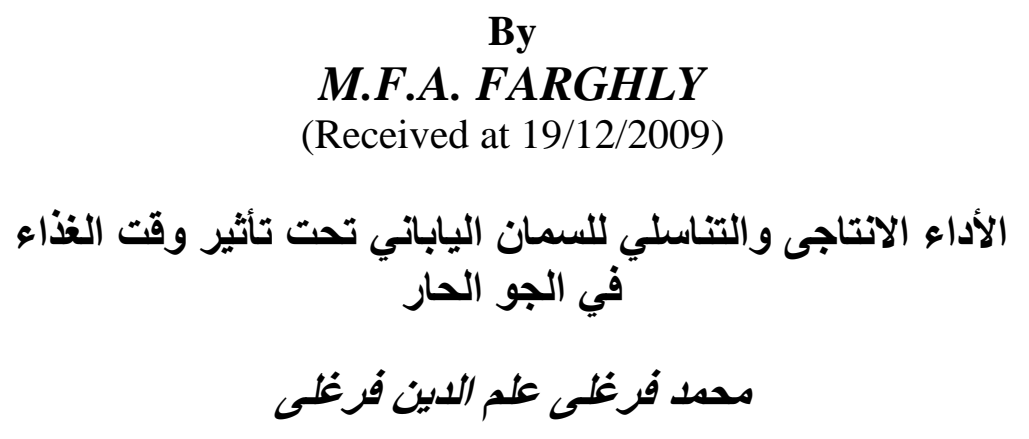

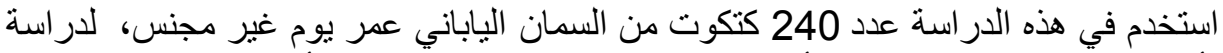

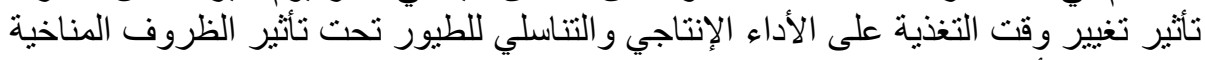

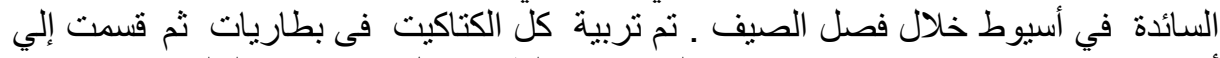

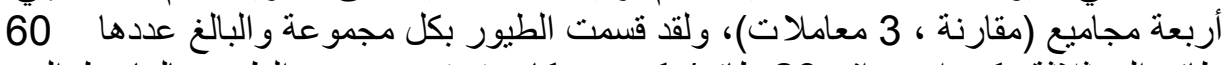

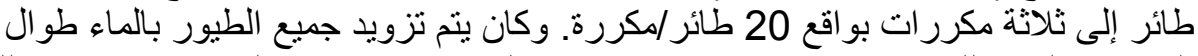

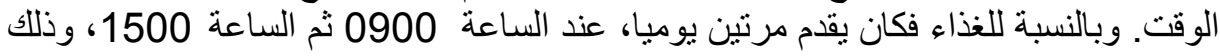

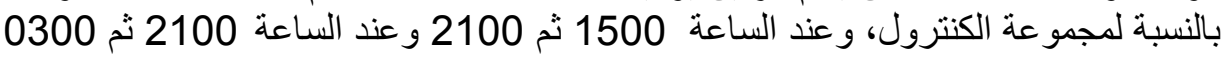

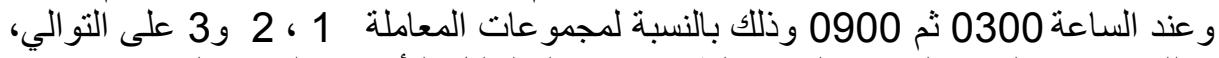

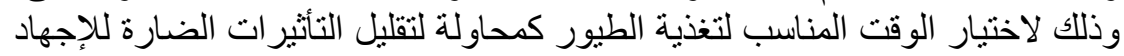

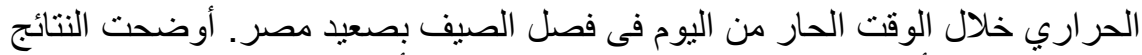

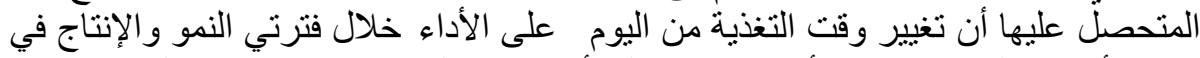

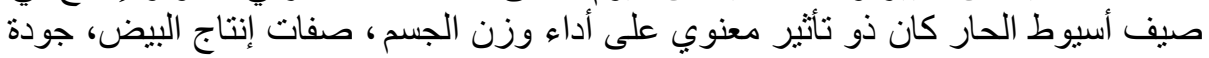

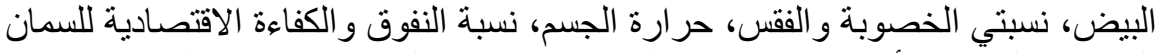
الياباني، ولكنه ذو تأثثر غير معنوي على حلى نسب مكونات البيضة في جميع المجاميع.

\section{SUMMARY}

A total number of two hundred and forty unsexed one-day old chicks of Japanese quail were used to study the effect of feeding time management on the productive and reproductive performance of birds under subtropical prevailing environmental conditions in Assiut. All chicks were housed in batteries in 3 equal groups (3 replicates of 20 
birds each). All experimental birds were supplied with clean water all the time. The feed was offered twice daily, control group (C) was practiced at 0900 and $1500 \mathrm{~h}$, during the warmest time of the day. While, the first treatment group (T1) was fed at 1500 and $2100 \mathrm{~h}$; the second treatment group (T2) was fed at 2100 and $0300 \mathrm{~h}$ and the third treatment group (T3) was fed at 0300 and $0900 \mathrm{~h}$, during the temperate climatic conditions, in order to avoid the deleterious effect of the high temperature on the birds in the summer season under Upper Egypt conditions. The obtained results indicated that change of feeding time affected body weight performance, egg production, egg quality, fertility \& hatchability, body temperature, mortality rate and economical efficiency in Japanese quail, however no significant differences in percentages of egg components were found among all groups.

Key words: Productive and reproductive performance, time of feeding, hot climate, Japanese quail.

\section{INTRODUCTION}

In areas with warm to hot climates, poultry producers face the challenge of avoiding heat stress in their birds at the beginning of each summer. In today's ever-evolving poultry industry, practices in management and feeding system are among the most important points for poultry producers especially in Upper Egypt with hot climates, since it can relatively reduce the heat load. Birds are very susceptible to high ambient temperature because they have very few functional sweat glands and consequently they face difficulty in eliminating excess of body heat especially when temperature exceeds the appropriate thermo neutral zone (Carmen et al., 1990 and Marai et al., 2002). This effect leads to a remarkable depression in appetite, feed intake, metabolizable energy for growth and production and finally in decreased efficiency of feed utilization. Furthermore, there are disturbances in metabolism of energy, protein and mineral balances, enzymatic, hormonal secretion and blood metabolism. These disturbances lead to a pronounced decrease in production and reproduction performance of poultry as well as in resistance to diseases (Emara, 1982, Samara, et al., 1996 and Aengwanich, 2007b).

It is noteworthy that most of the bird's heat load comes from the feed, as consequences of digestion, absorption and nutrient assimilation or excretion. Because the nutrient reserves in the body are little, 
therefore the mentioned activities occur at fairly predictable times following feed intake. The findings of many researchers as Wilson et al. (1989), Saiful et al. (2002) and Yahav et al. (2004) revealed that the heat production associated with feeding is based on the early morning feeding of birds. This means if birds are fed at $0600 \mathrm{~h}$, then the peak heat load will be at $0900-1100 \mathrm{~h}$, which usually precedes the natural peak heat load in poultry facilities. Therefore, birds would be facing problematic conditions when the feeding time is at around 1000-1100 $\mathrm{h}$, as the heat of feed utilization coincides with the hottest part of the day especially in the summer season in the tropic and subtropic regions.

High temperature condition adversely affects production and reproduction of poultry (Marsden et al., 1987). Consequently, the main effect of high ambient temperatures on birds is the reduction in feed consumption, growth rates and carcass traits, thereby increasing the time needed to reach marketing weight and leading to lower efficiency and profitability of poultry meat production in hot climates (Geraert et al., 1996).

An adequate protection against heat is very important in poultry production, to avoid heat stress in hot climate (Aengwanich, 2007a). Changing of the feeding time from morning to afternoon was among many experimental alternatives used to raise eggshell quality of hens maintained under hot climate (Bootwalla et al., 1983; Wilson and Keeling, 1991). Moreover, poultry management practices do not normally allow hens to consume feed in the afternoon or evening when eggshell calcification normally occurs, especially under heat stress conditions. Whether feeding late during temperate time of the day can be used as a means to improve the feed conversion, fertility, hatchability percentages and eggshell quality. Therefore, the main objective of this study is change of feeding time to improve productive and reproductive performance of growing and laying Japanese quail in the summer under Upper Egypt conditions.

\section{MATERIALS and METHODS}

The present study was carried out at the research poultry farm of Animal and Poultry Production Department, Faculty of Agriculture, Assiut University, Assiut, Egypt. The experiment lasted during summer season (from May to November 2009), where the environmental temperature ranged between $19.8{ }^{\circ} \mathrm{C}$ at night to $35.8{ }^{\circ} \mathrm{C}$ at midday 
while, humidity was from 40 to $64 \%$ (Table 1). A total number of two hundred and forty, one-day old Japanese quail chicks (Coturnix coturnix japonica) were used in this study. All chicks were wing banded, individually weighed and randomly classified into four groups: group 1 as a control (C), and group 2, 3, 4 as the treatment (T1, T2 and T3). Birds per each group, 60 birds ( 30 males and 30 females), were housed in quail brooding batteries with $86 \mathrm{X} \square 50 \mathrm{X} \square 25 \mathrm{~cm}$ pens from hatch until sexual maturity of age. Subsequently the quail were transferred into productive battery individual cages $(20 \mathrm{X} \square 25 \mathrm{X} \square 30 \mathrm{~cm}$ ) throughout the laying period. Clean water was available for birds all the time. While, feed was offered twice daily, in the control group (C) at 0900 and $1500 \mathrm{~h}$. On the other hand, birds in the first treatment group (T1) was fed at 1500 and $2100 \mathrm{~h}$; T2 was fed at 2100 and $0300 \mathrm{~h}$; and T3 was fed at 0300 and $0900 \mathrm{~h}$. The composition and calculated analysis of the experimental diets are shown in Table (2).

The newly hatched chicks were exposed to continuous lighting for $24 \mathrm{hrs} /$ day during the first 3 days of age. Thereafter, the photoperiod was decreased gradually (one hr/wk) to be adjusted to 12 and $16 \mathrm{hrs}$ lighting regimens during the growing and laying periods, with light intensities of 10 and 20 Luxes, respectively. Three estimates for the indoor temperature and the relative humidity (\%) were recorded for both the control and the treatment groups throughout the experimental period using a thermo hygrograph at 8,10 and $12 \mathrm{AM}$ 4, 6 and $8 \mathrm{PM}$; and at 10 PM, 12 midnight and 2 AM, respectively. It is worth to mention that brooding, rearing and raising of all experimental birds were under the climatic environmental conditions in Assiut.

The body weight (BW) on individual basis, at $0,4,8,12,16,20$ and 24 weeks of age was recorded. The average body weight gain (BWG) was calculated biweekly from 0 to 8 weeks of age. The feed consumption (FC) was calculated periodically biweekly, from 0 to 24 weeks of age. The feed conversion values ( $\mathrm{g}$ feed/g gain, FCRg) were calculated periodically every four weeks, from 0 to 8 weeks of age and the feed conversion ratio values ( $\mathrm{g}$ feed/g egg mass, FCRe) were calculated periodically every four weeks, from 8 to 24 weeks of age. Egg weight, egg number and egg mass and egg production as hen-day egg production (HDP) were calculated periodically every four weeks, from 8 to 24 weeks of age. Body temperature $\left({ }^{\circ} \mathrm{C}\right)$ was measured by using a thermometer inserted into the rectum for 2 minutes at depth of 2 
$\mathrm{cm}$ during feeding time. Dead birds were recorded daily and expressed as percentage during the experimental period.

During the period from 12 to 24 weeks of the experiment, 360 fresh-laid eggs were taken, every four weeks, from each group to measure egg quality characteristics. Egg weight was recorded to the nearest 0.1 gram on the same day of collection using special automatic balance. The length and width of egg were determined using a sliding caliper and their egg shape index was determined according to Reddy et al. (1979). Egg shape indexes = (width of egg/length of egg) 100. All eggs were broken gently on a glass surface. The height of thick albumen and yolk were measured using a Micrometer, as described by Brant and Shrader (1952). The diameter of yolk was measured, using a sliding caliper. The yolk was separated from the albumen and weighted. Shells with membranes were dried and weighed to the nearest $0.01 \mathrm{gm}$. Haugh units were recorded for egg individually and calculated from the egg weight and albumen height (Doyon et al., 1986). The Haugh unit values were calculated for each egg using the formula: Haugh unit $=100$ $\log (\mathrm{H}-1.7 \mathrm{x} \mathrm{w} 0.37+7.6)$ Where: $\mathrm{H}=$ the observed height of the albumen in millimeters and $\mathrm{W}=$ weight of egg $(\mathrm{g})$. Also, the yolk index was calculated by dividing (yolk's height/ yolk's diameter) x100. Shell thickness of the dried shell (without membranes) was measured using shell thickness apparatus at four different regions of the shell (blunt, pointed and both sides) and the average was recorded (millimeters). The albumen weight was calculated by subtracting egg weight from shell and yolk weight. The three egg components were expressed as percentages of the egg weight. Eggs laid in both experimental groups were collected daily and stored 7 days at $15-18^{\circ} \mathrm{C}$ and $70-75 \%$ relative humidity before incubation. Five hatches were performed at 12, 16, 20 and 24 weeks of age. The incubation was carried out using automatic Paterzime setter and hatcher under the recommended temperature, humidity, ventilation and turning of the incubated eggs chicken. The fertility and hatchability percentages were calculated as follow:

Fertility $(\%)=($ Fertile eggs $) \times 100 /$ Total set eggs

True hatchability $(\%)=($ Viable hatched chicks $) \times 100 /$ fertile eggs

Economical efficiency was based on the costs of the feed consumed and the income/bird (body weight and fertile egg production). The net revenue per bird is estimated as the difference between the total income/bird (LE), (growth and fertile egg production) and the total costs of feed and others. The costs of the used rations were calculated 
according to the actual prices prevailing in the Egyptian market during the experiment.

Statistical analysis: Data collected were subjected to ANOVA by applying the General Linear Models Procedure of SAS software (SAS Institute, version 6.12, 1996). Duncan methods (1955) were used to detect significant of differences among means of different groups. The percentages of HDP, fertility and hatchability were transformed to Arcsin values before statistical analysis.

\section{RESULTS and DISCUSSSION}

1- Body weight (BW): The results presented in Table (3), showed significant differences $(\mathrm{P} \leq 0.05)$ in $\mathrm{BW}$ for all the experimental groups at all studied ages (C, T1, T2 and T3) except at 0 and 2 weeks of age. The average body weight $(\mathrm{ABW})$ of $\mathrm{T} 2$ significantly $(\mathrm{P} \leq 0.05)$ exceeded those of $\mathrm{C}$ and $\mathrm{T} 3$ at 6,8 and 12 weeks of age by 14.0, 15.4 and $15.4 \%$ as well as 8.4, 10.3 and $7.5 \%$, respectively. While the ABW of T1 had an intermediate value. The $\mathrm{ABW}$ in $\mathrm{T} 1$ and $\mathrm{T} 2$ significantly $(\mathrm{P} \leq 0.05)$ exceeded those of $\mathrm{C}$ at 4 and 16 weeks of age by 8.2 and $12.5 \%$ as well as 6.7 and $13.1 \%$, respectively. While the $\mathrm{ABW}$ of $\mathrm{T} 3 \mathrm{had}$ an intermediate value. The ABW of $\mathrm{T} 2$ significantly $(\mathrm{P} \leq 0.05)$ exceeded those of $\mathrm{C}, \mathrm{T} 1$ and $\mathrm{T} 3$ by $4.8,4.3 ; 9.5,8.8$ and $7.3,5.2 \%$ at 20 and 24 weeks of age, respectively. The overall mean of $\mathrm{T} 2$ had a significant higher $(\mathrm{P} \leq 0.05) \mathrm{ABW}$ than those of $\mathrm{C}$ and $\mathrm{T} 3$ by about 12.1 and $7.2 \%$, respectively, while the $\mathrm{ABW}$ of $\mathrm{T} 1 \mathrm{had}$ an intermediate value.

The remarkable increase of $\mathrm{ABW}$ of Japanese quail (JQ) fed at 2100 to $0300 \mathrm{~h}$ than those of birds fed at 0900 to 1500,1500 to 2100 , and 0300 to $0900 \mathrm{~h}$, could be attributed to feeding of birds during midnight, which more adequate ambient climatic temperature $\left(\mathrm{C}^{\circ}\right)$, consequently avoid the harmful effect of the high temperature in the summer season. Moreover, these results are in agreement with the findings of Wilson et al. (1989), who indicated that feeding birds during hot time of day may lead to increase heat load, due to the heat increment that happen during feed metabolism. These obtained results are also coincided with the results of Hassan et al. (2003), Bouvarel et al. (2004), and Farghly, (2008), who stated that birds fed at afternoon had significantly $(\mathrm{P} \leq 0.05)$ higher body weight than those of birds fed at midday. Moreover, Avila et al. (2003a) showed that time of feeding 6:30 AM had significantly $(\mathrm{P} \leq 0.05)$ higher body weight than those of 
birds fed at 3:30 PM due to the greater efficiency of feed utilization. On the other hand, Harms (1991) and Samara et al. (1996) found a decrease in body weight when the time of feeding was changed from the morning to the afternoon.

2- Body weight gain (BWG): The obtained results presented in Table (3), showed significant differences $(\mathrm{P} \leq 0.05)$ in $\mathrm{BWG}$ in the experimental four groups at all ages studied $(\mathrm{C}, \mathrm{T} 1, \mathrm{~T} 2$ and $\mathrm{T} 3)$ during the experimental periods except at 0-2 weeks of age. The ABWG of T1 and $\mathrm{T} 2$ were significantly $(\mathrm{P} \leq 0.05)$ higher than those of $\mathrm{C}$ and $\mathrm{T} 3$ during the period from 2 to 4 weeks of age by 12.0, 5.8 and 15.7, 9.2\%, respectively. The $\mathrm{T} 2$ significantly $(\mathrm{P} \leq 0.05)$ gained more than those of $\mathrm{C}$, T1 and T3 by $17.8,25.3 ; 3.4,7.6$ and $11.7,23.1$ from 4 to 6 and 6 to 8 weeks of age, respectively. The overall mean of $\mathrm{T} 2$ had a significantly higher $(\mathrm{P} \leq 0.05) \mathrm{ABWG}$ than those of $\mathrm{C}, \mathrm{T} 1$ and $\mathrm{T} 3$ by about $16.4,4.8$ and $10.8 \%$, respectively.

The BWG tended a similar trend to that of the BW. Exposure of birds to high temperature more than $35^{\circ} \mathrm{C}$ causes different detrimental changes in their biological functions, which lead to disturbances in metabolizable energy for growth. The obtained results are in partial agreement with the findings of Hassan et al. (2003), Bouvarel et al. (2004), and Farghly, (2008), who stated that birds fed at afternoon had significantly $(\mathrm{P} \leq 0.05)$ higher body weight gain than those of birds fed at midday. In contrast, Harms (1991) and Samara et al. (1996) found a decrease in chicken body weight when the time of feeding was changed from the morning to the afternoon. However, Bouvarel et al. (2004) found that hens did not utilize the energy of the feed as efficiently when birds fed at $0600 \mathrm{~h}$ as they did when fed at $1800 \mathrm{~h}$.

3- Feed consumption (FC): The obtained results presented in Table (3), showed insignificant differences in feed consumption (FC) values in the experimental four groups at all ages studied (C, T1, T2 and T3).

The deleterious effect of the high temperature on appetite of birds and consequently on their feed consumption is logic and expected, since most of the bird's heat load comes from the feed, as consequences of digestion, absorption and nutrient assimilation or excretion. These observations suggest insignificant increased feed intake of the quail birds fed during the period from 2100 to $0300 \mathrm{~h}$, which in turn increased the BW above those of quail fed during the period from 0900 to $1500 \mathrm{~h}$. Also, the results of Keshavarz, (1998) attributed the greater feed intake 
during the afternoon than during the morning to an increased appetite. Moreover, these herein results are in partial agreement with the findings of Veltmann et al. (1984), Al-Homidan and Robertson (2007), and Farghly (2008).

4- Feed conversion (FCR): Data presented in Table (3), showed significant $(\mathrm{P} \leq 0.05)$ differences in average feed conversion for growth (FCRg) values in the experimental four groups at all studied ages (C, T1, T2 and T3) during the experimental periods. The average FCRg of $\mathrm{T} 2$ significantly $(\mathrm{P} \leq 0.05)$ improved than those of $\mathrm{T} 3$, during the period from 0 to 2 weeks of age by $14.8 \%$ and than those of $\mathrm{C}$, during the period from 2 to 4 weeks of age by $12.1 \%$, respectively. The FCRg of $\mathrm{T} 2$ had significantly $(\mathrm{P} \leq 0.05)$ improved than that of $\mathrm{C}$ and $\mathrm{T} 1$, from 4 to 6 and 6 to 8 weeks of age by 15.9, 13.4 and 20.6 and $14.8 \%$, respectively. The overall mean FCRg of F for T1 and T2 significantly $(\mathrm{P} \leq 0.05)$ improved than that of $\mathrm{C}$ and $\mathrm{T} 3$ by $11.4,9.0$ and $19.6,17.9 \%$, respectively.

The average feed conversion for egg (FCRe) values had significant differences $(\mathrm{P} \leq 0.05)$ in the experimental four groups at all ages studied $(\mathrm{C}, \mathrm{T} 1, \mathrm{~T} 2$ and $\mathrm{T} 3)$ during the experimental periods. The birds of $\mathrm{T} 1$ and $\mathrm{T} 2$ had significantly $(\mathrm{P} \leq 0.05)$ better FCRe values than those of $\mathrm{C}$, during the periods from 8 to 12,12 to 16,16 to 20 and 20 to 24 weeks of age by 19.0, 27.6; 22.8, 24.8; 15.9, 23.9 and 22.8, 30.1\%, respectively. The birds of $\mathrm{T} 3$ had significantly $(\mathrm{P} \leq 0.05)$ better FCRe value than that of $\mathrm{C}$, during the period from 8 to 12 and 12 to 16 weeks of age by 12.0 and $14.1 \%$, respectively. The overall mean of FCRe values of $\mathrm{T} 1$ and $\mathrm{T} 2$ significantly $(\mathrm{P} \leq 0.05)$ improved than those of $\mathrm{C}$ by 19.8 and $26.5 \%$, respectively, while the FCRe of $\mathrm{T} 3$ had an intermediate value.

These obtained results are in agreement with the obtained findings by Keshavarz, (1998) who, found that the feed conversion (FCR) for broilers fed during the period from 1300 to $2100 \mathrm{~h}$, was superior to the other treatments. In the same trend, Abd El-Hakim and Abd-Elsamee (2003) and Farghly (2008) showed that feeding time significantly improved the feed conversion. Moreover, Roland et al. (1972) found that feeding the Japanese quail birds during the period from 1400 to $1000 \mathrm{~h}$ increased the FCR above those of quail birds fed from 0600 to $1400 \mathrm{~h}$. In the summer season, high temperature evokes different detrimental changes in biological functions of bird, which lead to remarkable depression in appetite, feed consumption, metabolizable 
energy for growth and decreased efficiency of feed utilization (Leeson, 1996 and Marai, et al., 2006).

5- Body temperature (BT): Data presented in Table (4), show significant differences $(\mathrm{P} \leq 0.05)$ in body temperature $\left({ }^{\circ} \mathrm{C}\right)$ in the experimental four groups $(\mathrm{C}, \mathrm{L} 1, \mathrm{~L} 2$ and L3) at all ages studied except at 0 and 2 weeks of age. The average body temperature (ABT) of T2 significantly $(\mathrm{P} \leq 0.05)$ decreased than those of $\mathrm{C}$ at $4,6,16$ and 20 weeks of age by $1.9,2.2,2.7$ and $3.0 \%$, respectively. The ART in T1, $\mathrm{T} 2$ and $\mathrm{T} 3$ significantly $(\mathrm{P} \leq 0.05)$ decreased than those of $\mathrm{C}$ at 8 and 12 weeks of age by $2.4,1.8 ; 3.6,3.5$ and $1.8,1.8 \%$, respectively. The ABT of $\mathrm{T} 2$ significantly $(\mathrm{P} \leq 0.05)$ decreased than those of $\mathrm{C}, \mathrm{T} 1$ and $\mathrm{T} 3$ by $2.2,3.3$ and $3.0 \%$ at 24 weeks of age, respectively.

It is well known that, adult birds are homeothermic and provided with physiological mechanisms by which they can maintain their deep body temperature constant within the thermoneutral zone. Most of the bird's heat load comes from digestion, absorption, assimilation of feed. Heat production peaks occur at 3 to $5 \mathrm{hrs}$ after feeding cause almost $100 \%$ increase in heat production as compared to unfed birds. The increase in heat production associated with about $+1^{\circ} \mathrm{C}$ rise in body temperature (Leeson and Summers, 2000, and Avila et al., 2003a). The findings of many researchers as Kohne et al. (1973), Cave, (1981) and Wilson et al. (1989) found that the heat production, associated with feeding, is based on the early morning feeding of birds. This means if birds are fed at $0600 \mathrm{~h}$, then the peak heat load will be at $0900-1100 \mathrm{~h}$, which usually precedes the natural peak heat load in poultry facilities. Koh et al. (2000) found that heat production in fasted birds was much lower than that in fed birds at $26^{\circ} \mathrm{C}$, changed little until $20^{\circ} \mathrm{C}$ and then increased steeply.

Wiernusz and Teeter (1993), observed that heat production and body temperature increased with feed intake at $24^{\circ} \mathrm{C}$. They also showed that there were no differences in body temperature between feeding systems at $35^{\circ} \mathrm{C}$, even though heat production increased with feed intake in broilers. Teeter et al. (1993) found that amount of feed intake did not consistently affect body temperature post feeding at $24^{\circ} \mathrm{C}$ or $35^{\circ} \mathrm{C}$ in broilers.

6- Mortality rate: The obtained results shown in Table (4), indicated that, the mortality rate of $\mathrm{T} 1, \mathrm{~T} 2$ and $\mathrm{T} 3$ decreased than those of $\mathrm{C}$ by $3.0,2.0,2.0 ; 0.6,1.6,0.4$ and 3.6, 3.6, $2.4 \%$, at $0-8,8-24$ and $0-24$ 
weeks of age, respectively. Exposing birds to high temperature during midnight (more than three hours/day for 8 weeks during the summer in Egypt) increased the mortality rate (Zeidan et al., 1997 and Marai et al., 2002). These results disagree with observations of Avila et al. (2003b), who found that the mortality rate was similar among the tested treatments; Birds in the first treatment feeding was at 6:30 AM; In the second treatments, 50\% feeding at 6:30 AM and 50\% at 3:30 PM; In the third treatment, the feeding was at 11:00 AM; and 3:30 PM.

7- Egg production (EP): The data presented in Table (5) revealed significant differences $(\mathrm{P} \leq 0.05)$ in the average egg weight $(\mathrm{EW})$, egg number (EN), hen day egg production (HDP) and egg mass (EM) among birds in the experimental four groups $(\mathrm{C}, \mathrm{L} 1, \mathrm{~L} 2$ and L3) at all ages studied during the experimental periods, except from 8-12, 12-16 and 16-20 weeks of age in the EW.

The averages of EN and HDP for $\mathrm{T} 1$ significantly $(\mathrm{P} \leq 0.05)$ exceeded those of $\mathrm{C}$ and $\mathrm{T} 3$, during the period from 8-12 weeks of age by 33.0 and $21.1 \%$, respectively. The averages of EN and HDP for T1, $\mathrm{T} 2$ and $\mathrm{T} 3$ significantly $(\mathrm{P} \leq 0.05)$ exceeded those of $\mathrm{C}$, during the period from 12-16 weeks of age by 19.3, 23.6 and $15.5 \%$, respectively. The averages of EN and HDP for T2 significantly $(\mathrm{P} \leq 0.05)$ exceeded those of C, T1 and T3 during the period from 16-20 and 20-24 weeks of age by $11.3,10.1 ; 29.6,29.0$ and $11.0,19.5 \%$, respectively. The overall mean of HDP for T2 exceeded significantly $(\mathrm{P} \leq 0.05)$ that of $\mathrm{C}$ by 28.3 $\%$, while, the overall mean of HDP for $\mathrm{T} 1$ had an intermediate value. The total average of EN for T2 significantly $(\mathrm{P} \leq 0.05)$ surpassed those of $\mathrm{C}$ and $\mathrm{T} 3$ by 28.4 and $17.5 \%$, respectively.

The average EW for $\mathrm{T} 2$ significantly $(\mathrm{P} \leq 0.05)$ increased more than those of $\mathrm{C}$, during the periods from 20-24 weeks of age by $8.0 \%$. The average $\mathrm{EM}$ for $\mathrm{T} 2$ significantly $(\mathrm{P} \leq 0.05)$ exceeded those of $\mathrm{C}$ from $8-12,16-20$ and 20-24 weeks of age by $36.8,32.0$ and $38.7 \%$, respectively while, the overall mean of EM for $\mathrm{T} 1$ had an intermediate value. Also, the average $\mathrm{EM}$ for $\mathrm{T} 1$ and $\mathrm{T} 2$ significantly $(\mathrm{P} \leq 0.05)$ increased than that of $\mathrm{C}$, from 12-16 weeks of age by 24.8 and $31.7 \%$, respectively. The total average of $\mathrm{EM}$ for $\mathrm{T} 2$ significantly $(\mathrm{P} \leq 0.05)$ exceeded those of C and T3 by 9.2 and $21.0 \%$, respectively.

The obtained results of egg production are coincided with observations of Wilson et al. (1989), who reported that the feeding time during hottest part of day is a factor that may lead to heat stress, due to 
the heat increment that happen during feed metabolism. The findings of Duncan and Hughes (1975), and Roland et al. (1972) suggest that the higher egg production rate increased feed intake in quail fed from 1400 to $2200 \mathrm{~h}$. Also, Hassan et al. (2003) found that Japanese quail fed from 1400 to $2200 \mathrm{~h}$ increased the egg production as compared to quail fed during 0600 to 1400. Moreover, the herein results agree with observations of Balnave (1977) and Farghly (2008) who found that the afternoon feeding resulted in a higher rate of egg production. Avila et al. (2003b) found that total EP of birds fed at 6:30 AM, as well as birds fed $50 \%$ of the feeding at 0630 and $50 \%$ at $1530 \mathrm{~h}$ was higher than that of other treatments. The average total egg production of birds fed at 11:00 AM had the smallest EP.

The results obtained by Brake and Peebles (1986) in chickens, indicated that changing the time of feeding of hens from morning to afternoon resulted in a reduction in egg production. Also, Harms (1991), found lower egg production in birds fed late in the day. However, Brake (1988), Wilson and Keeling (1991), and Samara et al. (1996) noted that afternoon feeding had no effect on egg production. The observations of Ndubuisi et al. (2008), revealed that the highest egg production could be achieved, when the ambient temperatures are within the neutrality range. However, Under high ambient temperature, core blood supply to the egg synthesizing rate is reduced through the endocrine mechanism, consequently a drop in egg number and egg weight.

These results of egg weight are in agreement with the findings of Farmer et al. (1983); Bootwalla et al. (1983); Brake and Peebles, (1986) who, found that afternoon feeding in chickens increased the egg weight. However, the average of egg weight from quail fed from 0200 to $1400 \mathrm{~h}$ was not different from egg weight produced from quail birds, fed from 1400 to 2200 h. Also, Harms, (1991), Wilson and Keeling, (1991), and Samara et al. (1996) found that egg weight was not affected by changing the feeding time from morning to afternoon.

8- Egg quality traits: The recorded data in Table (6), showed that, insignificant differences $(\mathrm{P} \leq 0.05)$ were found in average of egg weight (AEW) and egg components (Albumen\%, Yolk\%, Shell\%) as well as in the overall mean among all groups at all ages studied, while, there were significant differences $(\mathrm{P} \leq 0.05)$ in the egg shape index (ESI), egg yolk index (EYI), shell thickness (ST) and Haugh units (HU) values among the birds in the experimental four groups $(\mathrm{C}, \mathrm{T} 1, \mathrm{~T} 2$ and T3) during the experimental periods, except at 20 weeks of age for ESI, EYI and HU as 
well as at 12 weeks of age for ESI and at 16 weeks of age for EYI, respectively.

The ESI of $\mathrm{T} 2$ had significantly $(\mathrm{P} \leq 0.05)$ higher values by 5.9 and $4.7 \%$ at 16 and 24 weeks of age than those of $\mathrm{C}$, respectively. The average EYI of $\mathrm{T} 1$ and $\mathrm{T} 2$ had significantly higher $(\mathrm{P} \leq 0.05)$ than those of $\mathrm{C}$ at 12 weeks of age by 2.7 and $2.7 \%$, respectively. Also, The average EYI of T2 had significantly higher $(\mathrm{P} \leq 0.05)$ than those of $\mathrm{C}$ at 24 weeks of age by 2.7 and $8.9 \%$.

Concerning, the average Haugh units (HU) of $\mathrm{T} 1$ and $\mathrm{T} 2$ significantly $(\mathrm{P} \leq 0.05)$ increased than those of $\mathrm{C}$ and $\mathrm{T} 3$ at 12 weeks of age by 2.8, 2.7 and 3.7, 3.5, respectively. At 16 weeks of age the AHU of $\mathrm{T} 1$ and $\mathrm{T} 2$ significantly $(\mathrm{P} \leq 0.05)$ exceeded that of $\mathrm{C}$ by 2.9 and $4.7 \%$, respectively. At 24 weeks of age, the $\mathrm{HU}$ for $\mathrm{T} 2$ had significantly $(\mathrm{P} \leq 0.05)$ higher value than those of $\mathrm{C}$ and $\mathrm{T} 1$ by 3.9 and $4.0 \%$, respectively.

With regard to shell thickness (ST), the average ST of T2 was significantly $(\mathrm{P} \leq 0.05)$ higher values than those of $\mathrm{C}, \mathrm{T} 1$ and $\mathrm{T} 3$ at 12 and 24 weeks of age by $9.7,8.9 ; 10.8,11.5$ and $7.9,9.5 \%$, respectively. Also, the average ST of $\mathrm{T} 1$ and $\mathrm{T} 2$ was significantly $(\mathrm{P} \leq 0.05)$ higher values than those of $\mathrm{C}$ and $\mathrm{T} 3$ at 16 weeks of age by 8.6, 5.2 and 12.4, $8.9 \%$, respectively. At 20 weeks of age, the average ST of T2 was significantly $(\mathrm{P} \leq 0.05)$ higher value than those of $\mathrm{C}$ by $5.2 \%$, while, the average ST of $\mathrm{T} 1$ and $\mathrm{T} 3 \mathrm{had}$ an intermediate values.

These obtained results are in agreement with numerous observations of Lennards et al. (1981), who reported that commercial laying hens utilize more calcium for eggshell quality from afternoon consumption than from morning consumption and added that the time of calcium intake has an important role in the ability of laying hens to calcify eggshells. Also, Balnave, (1977), Bootwalla et al. (1983), Brake and Peebles (1986), Brake (1988), Harms, (1991) reported that egg shell thickness increased after changing feeding time from morning to afternoon. High temperatures are well known to increase respiratory rate resulting in respiratory alkalosis which alters the acid-base balance and blood $\mathrm{pH}$. A reduced bicarbonate concentration in a lumen of the shell gland during panting adversely affects egg shell quality. On the other hand, Wilson and Keeling (1991) and Samara et al. (1996) found no effect of feeding time on egg quality. 
9- Fertility and hatchability (\%): The results presented in Table (7) revealed significant differences $(\mathrm{P} \leq 0.05)$ in the average of fertility and hatchability percentage among the birds in the experimental four groups (C, T1, T2 and T3) at all hatches studied. At 12 weeks of age, the birds of $\mathrm{T} 2$ had significantly $(\mathrm{P} \leq 0.05)$ higher fertility percentages $(\mathrm{F} \%)$ as compared to the $\mathrm{C}, \mathrm{T} 1$ and $\mathrm{T} 3$ by $13.9,8.1$ and $12.1 \%$, respectively. The $\mathrm{T} 2$ had significantly $(\mathrm{P} \leq 0.05)$ higher $\mathrm{F} \%$ by $12.5,13.9$ and $15.11 \%$ than those of $\mathrm{C}$, while, T1 and T3 had an intermediate values. The overall mean of $\mathrm{F} \%$ for $\mathrm{T} 2$ exceeded significantly $(\mathrm{P} \leq 0.05)$ that of $\mathrm{C}$ by $13.9 \%$, respectively, while, $\mathrm{T} 1$ and $\mathrm{T} 3 \mathrm{had}$ an intermediate values. The birds of $\mathrm{T} 2$ had significantly $(\mathrm{P} \leq 0.05)$ higher hatchability percentages $(\mathrm{H} \%)$ as compared to the $\mathrm{C}$ and $\mathrm{T} 3$ by $9.2,4.8$ and 26.4, $6.5 \%$ at 12 and 24 weeks of age, respectively. While, T1 had an intermediate values. At 16 and 20 weeks of age, the $\mathrm{T} 2$ had significantly $(\mathrm{P} \leq 0.05)$ higher $\mathrm{H} \%$ by $31.4,13.5$ and $10.8,4.6 \%$ than those of $\mathrm{C}$ and $\mathrm{T} 1$, respectively. The overall mean of $\mathrm{H} \%$ for $\mathrm{T} 2$ exceeded significantly $(\mathrm{P} \leq 0.05)$ that of $\mathrm{C}$, $\mathrm{T} 1$ and $\mathrm{T} 3$ by $19.5,5.6$ and $6.9 \%$, respectively.

These results are in agreement with the findings of Hassan et al. (2003), who found that the average fertility was higher, when quails were fed during the period from 1400 to $2200 \mathrm{~h}$ than from 0600 to 1400 h. Also, Brake (1988) and Farghly et al. (2008) found that feeding hens in the afternoon resulted in higher fertility than those fed in the morning, whereas Bootwalla et al. (1983) found no effect of feeding time on fertility.

McDaniel et al. (1979), showed that the hatchability percentage was higher in quail fed from 1400 to $2200 \mathrm{~h}$ than that of birds fed from 0600 to $1400 \mathrm{~h}$. These results agree with the observations of Brake (1988) and Farghly et al. (2008), who postulated that afternoon feeding improves hatchability in broiler breeder. Conversely, the findings of Farmer et al. (1983) found that the afternoon feeding decreased the hatchability percentage.

The improvement in fertility and hatchability of quail birds fed from 2100 to $0300 \mathrm{~h}$ may attributed to increase of the Haugh units, egg shell thickness and egg production. The previous results agree with McDaniel et al. (1981) and North and Bell (1990) who, found positive correlations between fertility and hatchability with egg production.

10- Economical efficiency: The data presented in Table (8), showed that, birds fed from 2100 to $0300 \mathrm{~h}$ (T2) had higher economical efficiency than those of birds fed at 0900 to 1500,1500 to 2100 , and 
0300 to $0900 \mathrm{~h}(\mathrm{C}, \mathrm{T} 1$ and T3) during growing and laying periods, since, it amounted 100, 122.6, 137.9 and 101.6 for growing period as well as100, 132.0, 170.3 and 116.7 for laying period, respectively. The obtained results are also in harmony with the findings of Farghly et al. (2008), who found remarkable increase in economical efficiency of JQ fed at 2100 to $0300 \mathrm{~h}$ followed by birds fed at 1500 to 2100 than those of birds fed at 0900 to 1500, and 0300 to 0900 h. Also, Abd El-Hakim and Abd-Elsamee, (2003), evaluated the effect of four different feeding systems (skip a day and skip a half day i.e. $12 \mathrm{hr}$ feed $+12 \mathrm{hr}$ fast) during summer season for the Arbor Acres broiler chicks significantly improved the performance parameters and economical efficiency.

It could be concluded that the feeding birds at 2100 to $0300 \mathrm{~h}$ (T2) was more economical efficient than those of birds fed at 0900 to 1500 (C) and 0300 to $0900 \mathrm{~h}$ (T3). This could be attributed to the superiority of $\mathrm{T} 2$ in body weight performance, egg production, egg quality and lower mortality percentages, as well as having adequate percentages fertility and hatchability. In addition, T2 decreased the body temperature of birds, which positively reflected on the health condition of the birds, while the T1 had an intermediate value. The feeding at 2100 to $0300 \mathrm{~h}$ for growing and laying Japanese quail is highly recommended.

Table 1: The overall means of indoor temperature and relative humidity values of during the experimental period.

\begin{tabular}{|c|c|c|c|c|l|l|}
\hline \multirow{2}{*}{$\begin{array}{c}\text { Intervals } \\
(\text { month) }\end{array}$} & \multicolumn{3}{|c|}{ Temperature $\left(\mathrm{C}^{\circ}\right)$} & \multicolumn{3}{c|}{ Humidity (\%) } \\
\cline { 2 - 7 } & Max. & Min & Av. & Max. & Min. & Av. \\
\hline Jun & 32.6 & 23.6 & 28.1 & 62.1 & 41.8 & 52.0 \\
\hline Jul & 33.5 & 25.6 & 29.6 & 60.6 & 39.6 & 50.1 \\
\hline Aug & 35.8 & 26.8 & 31.3 & 59.8 & 40.4 & 50.1 \\
\hline Sep & 35.6 & 26.3 & 31.0 & 60.3 & 42.1 & 51.2 \\
\hline Oct & 34.5 & 24.7 & 29.6 & 62.5 & 44.4 & 53.5 \\
\hline Nov & 32.8 & 22.9 & 27.9 & 64.8 & 42.8 & 53.8 \\
\hline Overall mean & 33.5 & 24.2 & 28.9 & 61.9 & 42.1 & 52.0 \\
\hline
\end{tabular}

Max = Maximum Min= Minimum Av. = Average 
Table 2: Composition and calculation analysis of the experimental diets.

\begin{tabular}{|l|c|c|}
\hline \multicolumn{1}{|c|}{ Ingredients } & Starter (\%) & Layer (\%) \\
\hline Yellow corn & 53.0 & 52.3 \\
\hline Soybean meal (44\%) & 34.6 & 31.7 \\
\hline Concentrate & $12.0^{*}$ & $10.0 * *$ \\
\hline Salt & 0.25 & 0.50 \\
\hline Dicalcium phosphate & 0.15 & 1.50 \\
\hline Limestone & --- & 4.00 \\
\hline Total & 100 & 100 \\
\hline \multicolumn{2}{|c|}{ Calculated analysis*** } \\
\hline Protein (\%) & 26.0 & 23.6 \\
\hline ME ( KCal/ Kg diet) & 2850 & 2775 \\
\hline Calcium (\%) & 0.90 & 2.75 \\
\hline Available phosphorus (\%) & 0.45 & 0.75 \\
\hline
\end{tabular}

* Broiler concentrate contains:

$52 \%$ crude protein $\quad 1.6 \%$ crude fiber

$3.5 \%$ available phosphorus $1.5 \%$ methionine

$6.1 \%$ ether extract

$7 \%$ calcium $2.1 \%$ methionine and cystine $\quad 3.0 \%$ lysine $2416 \mathrm{kcal} / \mathrm{kg}$ metabolizable energy.

Each Kilogram of broiler concentrate contains the following levels of vitamins and minerals: vit. A 130,000 IU; D3 26,000 IU; vit. E $120 \mathrm{IU}$; vit B12 150 ug; vit. K3 MSB 16 mg; vit B2 $50 \mathrm{mg}$; capantothenate B3 $120 \mathrm{mg}$; nicotinic acid PP $250 \mathrm{mg}$; thiamine B1 $25 \mathrm{mg}$; folic acid $15 \mathrm{mg}$; pyridoxine B6 $15 \mathrm{mg}$; betain-Choline- $\mathrm{HCl} 5000 \mathrm{mg}$; Mn $700 \mathrm{mg}$;Zn 600 $\mathrm{mg}$; Fe $400 \mathrm{mg}$;Cu $40 \mathrm{mg}$; Iodine $7 \mathrm{mg}$; Co $2 \mathrm{mg}$; Se $1.5 \mathrm{mg}$; B.H.T. $1250 \mathrm{mg}$; Zinc baciteracin $150 \mathrm{mg}$.

\section{** The layer concentrate contains:}

- Crude protein

- Crude fiber

- Crude fat

- Methionine

- Methionine + Cystine
$51.00 \%$

$2.00 \%$

$6.40 \%$

$1.67 \%$

$2.25 \%$
- Lysine

- Calcium

- Available phosphorus

- Salt

- Metabolizable energy $2400 \mathrm{kcal} /$ diet

Each Kilogram of layer concentrate contains the following levels of vitamins and minerals:

- Vit. A

- Vit. E

- Vit. D3

- Vit. K

- Vit. B1

- Vit. B2

- Vit. B6

- Vit. B12

- Pantothenic acid

- Niacin
$10000 \mathrm{IU}$

$100 \mathrm{mg}$

$2500 \mathrm{IU}$

$25 \mathrm{mg}$

$100 \mathrm{mg}$

$40 \mathrm{mg}$

$15 \mathrm{mg}$

$200 \mathrm{mg}$

$100 \mathrm{mg}$

$400 \mathrm{mg}$

*** Calculated according to NRC (1994).

- Folic acid

- Biotin

- Chorine chloride

- Iron

- Zinc

- Copper

- Iodine

- Selenium

- Manganese

- Antioxidant
$3.30 \%$

$8.00 \%$

$3.00 \%$

$3.19 \%$

$10 \mathrm{mg}$

$500 \mathrm{mg}$

$5000 \mathrm{mg}$

$400 \mathrm{mg}$

$560 \mathrm{mg}$

$5 \mathrm{mg}$

$3 \mathrm{mg}$

$1 \mathrm{mg}$

$620 \mathrm{mg}$

$75 \mathrm{mg}$ 
Table 3: Means \pm SE of body weight, body weight gain, feed consumption and feed conversion traits of growing and laying Japanese quail as affected by feeding time.

\begin{tabular}{|c|c|c|c|c|c|}
\hline \multirow{2}{*}{ Traits } & \multirow{2}{*}{$\begin{array}{l}\text { Age } \\
\text { (wks) }\end{array}$} & \multicolumn{4}{|c|}{ Treatments } \\
\hline & & $\mathrm{C}$ & $\mathrm{T} 1$ & $\mathrm{~T} 2$ & $\mathrm{~T} 3$ \\
\hline \multirow{9}{*}{ Body weight (g) } & 0 & $7.52 \pm 0.88$ & $7.81 \pm 0.96$ & $7.42 \pm 1.11$ & $7.61 \pm 0.67$ \\
\hline & 2 & $51.0 \pm 3.32$ & $52.6 \pm 2.83$ & $55.3 \pm 1.82$ & $53.1 \pm 4.11$ \\
\hline & 4 & $115.2^{b} \pm 3.93$ & $124.6^{\mathrm{a}} \pm 4.68$ & $129.6^{\mathrm{a}} \pm 3.35$ & $121.1^{\mathrm{ab}} \pm 5.94$ \\
\hline & 6 & $161.7^{\mathrm{c}} \pm 4.21$ & $177.4^{\mathrm{ab}} \pm 5.90$ & $184.4^{\mathrm{a}} \pm 3.56$ & $170.1^{\mathrm{bc}} \pm 6.12$ \\
\hline & 8 & $185.6^{\mathrm{c}} \pm 6.92$ & $205.1^{\mathrm{ab}} \pm 5.31$ & $214.2^{\mathrm{a}} \pm 4.12$ & $194.3^{b c} \pm 5.91$ \\
\hline & 12 & $187.4^{\mathrm{c}} \pm 8.83$ & $205.5^{\mathrm{ab}} \pm 6.22$ & $216.2^{\mathrm{a}} \pm 3.92$ & $201.6^{b} \pm 3.93$ \\
\hline & 16 & $193.6^{\mathrm{b}} \pm 6.25$ & $206.6^{\mathrm{a}} \pm 7.36$ & $215.7^{\mathrm{a}} \pm 5.56$ & $203.2^{\mathrm{ab}} \pm 5.94$ \\
\hline & 20 & $200.0^{\mathrm{b}} \pm 5.92$ & $208.8^{\mathrm{b}} \pm 3.01$ & $218.9^{\mathrm{a}} \pm 4.91$ & $204.1^{\mathrm{b}} \pm 3.95$ \\
\hline & 24 & $202.0^{\mathrm{c}} \pm 4.84$ & $210.8^{b} \pm 4.56$ & $219.8^{\mathrm{a}} \pm 2.52$ & $208.9^{c} \pm 4.75$ \\
\hline \multicolumn{2}{|c|}{ Overallmean } & $144.9^{c} \pm 5.32$ & $155.4^{\mathrm{ab}} \pm 6.23$ & $162.4^{\mathrm{a}} \pm 3.85$ & $151.5^{b c} \pm 4.15$ \\
\hline \multirow{4}{*}{$\begin{array}{l}\text { Body weight } \\
\text { gain } \\
\text { (g/bird/day) }\end{array}$} & $0-2$ & $3.11 \pm 1.22$ & $3.20 \pm 0.66$ & $3.42 \pm 0.55$ & $3.25 \pm 0.86$ \\
\hline & $2-4$ & $4.59^{c} \pm 1.31$ & $5.14^{\mathrm{a}} \pm 1.10$ & $5.31^{\mathrm{a}} \pm 0.75$ & $4.86^{\mathrm{b}} \pm 1.21$ \\
\hline & $4-6$ & $3.32^{c} \pm 1.02$ & $3.78^{\mathrm{b}} \pm 1.16$ & $3.91^{\mathrm{a}} \pm 1.02$ & $3.50^{\mathrm{b}} \pm 1.22$ \\
\hline & $6-8$ & $1.70^{\mathrm{c}} \pm 0.32$ & $1.98^{\mathrm{b}} \pm 0.22$ & $2.13^{\mathrm{a}} \pm 0.25$ & $1.73^{c} \pm 0.18$ \\
\hline \multicolumn{2}{|c|}{ Overallmean } & $3.18^{c} \pm 1.08$ & $3.52^{b} \pm 0.92$ & $3.69^{\mathrm{a}} \pm 0.78$ & $3.33^{c} \pm 1.03$ \\
\hline \multirow{8}{*}{$\begin{array}{l}\text { Average feed } \\
\text { consumption } \\
\text { (g/bird/day) }\end{array}$} & $0-2$ & $7.89 \pm 0.90$ & $8.11 \pm 0.67$ & $7.72 \pm 0.75$ & $8.02 \pm 0.88$ \\
\hline & $2-4$ & $11.98 \pm 0.85$ & $12.22 \pm 1.11$ & $12.11 \pm 0.62$ & $12.13 \pm 1.11$ \\
\hline & $4-6$ & $13.82 \pm 1.20$ & $13.81 \pm 0.92$ & $14.01 \pm 0.74$ & $13.86 \pm 0.98$ \\
\hline & $6-8$ & $16.23 \pm 0.88$ & $16.41 \pm 0.98$ & $16.81 \pm 1.11$ & $16.22 \pm 1.21$ \\
\hline & $8-12$ & $16.22 \pm 1.31$ & $16.14 \pm 1.22$ & $17.47 \pm 1.03$ & $16.26 \pm 1.22$ \\
\hline & $12-16$ & $17.96 \pm 2.12$ & $18.24 \pm 1.63$ & $18.91 \pm 1.21$ & $18.33 \pm 1.61$ \\
\hline & $16-20$ & $19.62 \pm 1.81$ & $19.91 \pm 1.61$ & $20.92 \pm 1.12$ & $20.20 \pm 1.43$ \\
\hline & $20-24$ & $19.88 \pm 1.51$ & $19.94 \pm 1.32$ & $21.20 \pm 0.92$ & $20.30 \pm 1.59$ \\
\hline \multicolumn{2}{|c|}{ Overallmean } & $15.41 \pm 1.24$ & $15.58 \pm 1.19$ & $16.14 \pm 0.93$ & $15.68 \pm 1.02$ \\
\hline \multirow{4}{*}{$\begin{array}{l}\text { Feed conversion } \\
\text { (g feed/g gain) }\end{array}$} & $0-2$ & $2.51^{\mathrm{ab}} \pm 0.22$ & $2.53^{\mathrm{ab}} \pm 0.33$ & $2.23^{\mathrm{b}} \pm 0.12$ & $2.56^{\mathrm{a}} \pm 0.43$ \\
\hline & $2-4$ & $2.60^{\mathrm{a}} \pm 0.38$ & $2.37^{\mathrm{ab}} \pm 0.41$ & $2.32^{\mathrm{b}} \pm 0.18$ & $2.49^{\mathrm{ab}} \pm 0.52$ \\
\hline & $4-6$ & $4.15^{\mathrm{a}} \pm 0.61$ & $3.66^{\mathrm{bc}} \pm 0.37$ & $3.58^{\mathrm{c}} \pm 0.22$ & $3.94^{\mathrm{ab}} \pm 0.42$ \\
\hline & $6-8$ & $9.51^{\mathrm{a}} \pm 0.53$ & $8.28^{\mathrm{b}} \pm 0.54$ & $7.88^{\mathrm{bc}} \pm 0.38$ & $9.38^{\mathrm{ab}} \pm 0.63$ \\
\hline \multicolumn{2}{|c|}{ Overallmean } & $4.69^{\mathrm{a}} \pm 0.38$ & $4.21^{b} \pm 0.35$ & $3.92^{\mathrm{bc}} \pm 0.20$ & $4.59^{\mathrm{a}} \pm 0.51$ \\
\hline \multirow{4}{*}{$\begin{array}{c}\text { Feed conversion } \\
\text { (g feed/g egg } \\
\text { mass) }\end{array}$} & $8-12$ & $3.93^{\mathrm{a}} \pm 0.02$ & $3.30^{\mathrm{b}} \pm 0.12$ & $3.08^{\mathrm{c}} \pm 0.05$ & $3.51^{\mathrm{b}} \pm 0.08$ \\
\hline & $12-16$ & $2.91^{\mathrm{a}} \pm 0.22$ & $2.37^{\mathrm{b}} \pm 0.12$ & $2.33^{\mathrm{b}} \pm 0.04$ & $2.55^{\mathrm{b}} \pm 0.10$ \\
\hline & $16-20$ & $2.70^{\mathrm{a}} \pm 0.03$ & $2.33^{\mathrm{b}} \pm 0.06$ & $2.18^{\mathrm{b}} \pm 0.10$ & $2.64^{\mathrm{a}} \pm 0.12$ \\
\hline & $20-24$ & $3.07^{\mathrm{a}} \pm 0.05$ & $2.50^{\mathrm{b}} \pm 0.21$ & $2.36^{\mathrm{b}} \pm 0.08$ & $2.82^{\mathrm{ab}} \pm 0.18$ \\
\hline \multicolumn{2}{|c|}{ Overallmean } & $3.15^{\mathrm{a}} \pm 0.11$ & $2.63^{b} \pm 0.12$ & $2.49^{b} \pm 0.05$ & $2.88^{\mathrm{ab}} \pm 0.23$ \\
\hline
\end{tabular}

${ }_{\mathrm{a}, \mathrm{b} \text { and } \mathrm{c}}$ Means within each row for each division (C,T1, T2 and T3) with no common superscripts are significantly different $(\mathrm{P} \leq 0.05)$.

$\mathrm{C}=\mathrm{Control}$ group (birds were fed at 0900 and $1500 \mathrm{~h}$ )

$\mathrm{T} 1=$ Treatment group (birds were fed at 1500 and $2100 \mathrm{~h}$ )

$\mathrm{T} 2=$ Treatment group (birds were fed at 2100 and $0300 \mathrm{~h}$ )

$\mathrm{T} 3=$ Treatment group (birds were fed at 0300 and $0900 \mathrm{~h}$ ) 
Table 4: Means $\pm \mathrm{SE}$ of Body temperature and mortality rate of growing and laying Japanese quail as affected by feeding time.

\begin{tabular}{|c|c|c|c|c|c|}
\hline \multirow{2}{*}{ Traits } & Age & \multicolumn{4}{|c|}{ Treatments } \\
\cline { 2 - 6 } & $(\mathrm{wks})$ & $\mathrm{C}$ & $\mathrm{T} 1$ & $\mathrm{~T} 2$ & $\mathrm{~T} 3$ \\
\hline \multirow{4}{*}{$\begin{array}{c}\text { Body temp. } \\
\left(\mathrm{C}^{\circ}\right)\end{array}$} & 0 & $40.02 \pm 0.48$ & $39.75 \pm 0.46$ & $39.64 \pm 0.11$ & $40.01 \pm 0.67$ \\
\cline { 2 - 6 } & 2 & $40.42 \pm 0.32$ & $40.61 \pm 0.43$ & $40.38 \pm 0.52$ & $40.41 \pm 0.11$ \\
\cline { 2 - 6 } & 4 & $40.89^{\mathrm{a}} \pm 0.53$ & $40.62^{\mathrm{ab}} \pm 0.28$ & $40.11^{\mathrm{b}} \pm 0.15$ & $40.92^{\mathrm{ab}} \pm 0.54$ \\
\cline { 2 - 6 } & 6 & $41.22^{\mathrm{a}} \pm 0.21$ & $40.66^{\mathrm{bc}} \pm 0.40$ & $40.32^{\mathrm{c}} \pm 0.26$ & $40.92^{\mathrm{ab}} \pm 0.12$ \\
\cline { 2 - 6 } & 12 & $41.86^{\mathrm{a}} \pm 0.32$ & $40.88^{\mathrm{b}} \pm 0.11$ & $40.42^{\mathrm{c}} \pm 0.12$ & $41.12^{\mathrm{b}} \pm 0.41$ \\
\cline { 2 - 6 } & 16 & $42.11^{\mathrm{a}} \pm 0.23$ & $41.22^{\mathrm{b}} \pm 0.22$ & $40.52^{\mathrm{c}} \pm 0.32$ & $41.22^{\mathrm{b}} \pm 0.33$ \\
\cline { 2 - 6 } & 20 & $41.86^{\mathrm{a}} \pm 0.32$ & $41.66^{\mathrm{ab}} \pm 0.16$ & $41.02^{\mathrm{c}} \pm 0.26$ & $41.56^{\mathrm{bc}} \pm 0.34$ \\
\cline { 2 - 6 } & 24 & $42.01^{\mathrm{a}} \pm 0.24$ & $41.56^{\mathrm{a}} \pm 0.26$ & $40.65^{\mathrm{b}} \pm 0.31$ & $41.62^{\mathrm{a}} \pm 0.35$ \\
\hline \multirow{3}{*}{$\begin{array}{c}\text { Mortality } \\
\text { rate }(\%)\end{array}$} & $0-8$ & 4.2 & 1.2 & 2.2 & $41.89^{\mathrm{a}} \pm 0.25$ \\
\cline { 2 - 6 } & $8-24$ & 1.8 & 1.2 & 2.6 & 6.2 \\
\cline { 2 - 6 } & $0-24$ & 6.0 & 2.4 & 4.8 & 10.6 \\
\hline
\end{tabular}

a, b and c Means within each row for each division (C,T1, T2 and T3) with no common superscripts are significantly different $(\mathrm{P} \leq 0.05)$.

$\mathrm{C}=$ Control group (birds were fed at 0900 and $1500 \mathrm{~h}$ ) $\quad \mathrm{T} 1=$ Treatment group (birds were fed at 1500 and $2100 \mathrm{~h}$ )

$\mathrm{T} 2=$ Treatment group (birds were fed at 2100 and $0300 \mathrm{~h}$ )

$\mathrm{T} 3=$ Treatment group (birds were fed at 0300 and $0900 \mathrm{~h}$ )

Table 5: Means \pm SE of egg number, hen day egg production, egg weight and egg mass for Japanese quail as affected by feeding time.

\begin{tabular}{|c|c|c|c|c|c|}
\hline \multirow{2}{*}{ Traits } & \multirow{2}{*}{ Periods } & \multicolumn{4}{|c|}{ Treatments } \\
\hline & & $\mathrm{C}$ & T1 & $\mathrm{T} 2$ & T3 \\
\hline \multirow{5}{*}{$\begin{array}{c}\text { Egg number } \\
\text { (egg/hen } / 28 \\
\text { days) }\end{array}$} & P1 (8 -12w) & $11.2^{\mathrm{b}} \pm 1.1$ & $13.0^{\mathrm{ab}} \pm 1.89$ & $14.9^{\mathrm{a}} \pm 0.86$ & $12.3^{\mathrm{b}} \pm 1.2$ \\
\hline & P2 (12 -16 w) & $16.1^{\mathrm{b}} \pm 0.5$ & $19.2^{\mathrm{a}} \pm 1.2$ & $19.9^{\mathrm{a}} \pm 1.0$ & $18.6^{\mathrm{a}} \pm 1.3$ \\
\hline & P3 (16- $20 \mathrm{w})$ & $18.2^{c} \pm 0.72$ & $21.2^{\mathrm{b}} \pm 0.82$ & $23.6^{\mathrm{a}} \pm 0.66$ & $19.1^{\mathrm{c}} \pm 0.91$ \\
\hline & P4 (20- $24 \mathrm{w})$ & $16.2^{\mathrm{c}} \pm 1.2$ & $18.9^{\mathrm{b}} \pm 1.1$ & $20.8^{a} \pm 0.71$ & $17.4^{\mathrm{bc}} \pm 0.83$ \\
\hline & Total & $61.7^{\mathrm{c}} \pm 1.1$ & $72.3^{\mathrm{ab}} \pm 1.2$ & $79.2^{\mathrm{a}} \pm 0.51$ & $67.4^{b c} \pm 0.72$ \\
\hline \multirow{5}{*}{$\begin{array}{l}\text { Egg weight } \\
\text { (g) }\end{array}$} & $\mathrm{P} 1(8-12 \mathrm{w})$ & $10.3 \pm 0.31$ & $10.5 \pm 0.21$ & $10.6 \pm 0.12$ & $10.5 \pm 0.23$ \\
\hline & $\mathrm{P} 2(12-16 \mathrm{w})$ & $10.7 \pm 0.42$ & $11.2 \pm 0.33$ & $11.4 \pm 0.22$ & $10.8 \pm 0.42$ \\
\hline & P3 (16- $20 \mathrm{w})$ & $11.2 \pm 0.51$ & $11.3 \pm 0.32$ & $11.4 \pm 0.15$ & $11.2 \pm 0.41$ \\
\hline & P4 (20- $24 \mathrm{w})$ & $11.2^{\mathrm{b}} \pm 0.66$ & $11.8^{\mathrm{ab}} \pm 0.21$ & $12.1^{\mathrm{a}} \pm 0.22$ & $11.6^{\mathrm{ab}} \pm 0.36$ \\
\hline & Overallmean & $10.9 \pm 0.48$ & $11.2 \pm 0.31$ & $11.4 \pm 0.20$ & $11.0 \pm 0.41$ \\
\hline \multirow{5}{*}{$\operatorname{HDP}(\%)$} & $\mathrm{P} 1(8-12 \mathrm{w})$ & $40.0^{\mathrm{b}} \pm 0.41$ & $46.4^{\mathrm{ab}} \pm 0.36$ & $53.2^{\mathrm{a}} \pm 0.22$ & $43.9^{\mathrm{ab}} \pm 0.33$ \\
\hline & P2 $(12-16 w)$ & $57.5^{\mathrm{b}} \pm 0.31$ & $68.6^{\mathrm{a}} \pm 0.31$ & $71.1^{\mathrm{a}} \pm 0.36$ & $66.4^{\mathrm{a}} \pm 0.32$ \\
\hline & P3 (16- $20 \mathrm{w})$ & $65.0^{\mathrm{c}} \pm 0.45$ & $75.7^{\mathrm{b}} \pm 0.41$ & $81.3^{a} \pm 0.29$ & $68.2^{\mathrm{c}} \pm 0.28$ \\
\hline & $\mathrm{P} 4(20-24 \mathrm{w})$ & $57.9^{c} \pm 0.55$ & $67.5^{\mathrm{b}} \pm 0.22$ & $74.3^{a} \pm 0.28$ & $62.1^{\mathrm{bc}} \pm 0.41$ \\
\hline & Overallme & $55.1^{\mathrm{c}} \pm 0.46$ & $64.6^{\mathrm{ab}} \pm 0.38$ & $70.7^{\mathrm{a}} \pm 0.25$ & $60.2^{\mathrm{bc}} \pm 0.38$ \\
\hline \multirow{5}{*}{$\begin{array}{c}\text { Egg mass } \\
(\mathrm{g} / \mathrm{hen} / 28 \\
\text { days })\end{array}$} & P1 (8 -12w) & $115.4^{\mathrm{b}} \pm 4.2$ & $136.5^{\mathrm{ab}} \pm 5.2$ & $157.9^{\mathrm{a}} \pm 4.1$ & $129.2^{\mathrm{ab}} \pm 5.1$ \\
\hline & P2 (12 -16w) & $172.3^{\mathrm{b}} \pm 3.6$ & $215.0^{\mathrm{a}} \pm 4.1$ & $226.9^{\mathrm{a}} \pm 3.9$ & $200.9^{\mathrm{ab}} \pm 4.2$ \\
\hline & P3 (16- $20 \mathrm{w})$ & $203.8^{\mathrm{c}} \pm 4.8$ & $239.6^{\mathrm{ab}} \pm 3.8$ & $269.0^{\mathrm{a}} \pm 3.5$ & $213.9^{b c} \pm 3.5$ \\
\hline & P4 (20- $24 \mathrm{w})$ & $181.4^{\mathrm{c}} \pm 4.2$ & $223.0^{\mathrm{ab}} \pm 3.2$ & $251.7^{\mathrm{a}} \pm 2.6$ & $201.8^{b c} \pm 4.2$ \\
\hline & Total & $745.8^{c} \pm 5.2$ & $905.5^{\mathrm{ab}} \pm 4.7$ & $814.1^{\mathrm{a}} \pm 3.2$ & $672.9^{\mathrm{c}} \pm 4.4$ \\
\hline
\end{tabular}


Table 6: Means \pm SE of egg quality parameters and egg components for Japanese quail as affected by feeding time.

\begin{tabular}{|c|c|c|c|c|}
\hline \multirow{2}{*}{ Traits } & \multicolumn{4}{|c|}{ Treatments } \\
\hline & $\mathrm{C}$ & $\mathrm{T} 1$ & $\mathrm{~T} 2$ & T3 \\
\hline \multicolumn{5}{|l|}{ At 12 wks of age } \\
\hline Egg weight $(\mathrm{g})$ & $10.8 \pm 0.21$ & $10.9 \pm 0.18$ & $11.0 \pm 0.32$ & $10.8 \pm 0.36$ \\
\hline Egg shape index $(\%)$ & $72.8 \pm 0.56$ & $73.3 \pm 0.82$ & $74.2 \pm 0.811$ & $73.4 \pm 0.56$ \\
\hline Egg yolk index $(\%)$ & $56.6^{\mathrm{b}} \pm 0.44$ & $58.2^{\mathrm{a}} \pm 0.68$ & $58.1^{\mathrm{a}} \pm 0.82$ & $57.6^{\mathrm{ab}} \pm 0.47$ \\
\hline Haugh units & $90.1^{\mathrm{b}} \pm 0.59$ & $92.6^{\mathrm{a}} \pm 1.21$ & $93.4^{\mathrm{a}} \pm 1.01$ & $90.2^{\mathrm{b}} \pm 0.55$ \\
\hline Egg shell thickness $(\mathrm{x} 0.01 \mathrm{~mm})$ & $18.6^{\mathrm{b}} \pm 0.38$ & $19.3^{\mathrm{b}} \pm 0.41$ & $20.6^{\mathrm{a}} \pm 0.41$ & $19.1^{\mathrm{b}} \pm 0.39$ \\
\hline Albumen $(\%)$ & $55.62 \pm 1.65$ & $55.71 \pm 1.95$ & $55.40 \pm 1.95$ & $55.41 \pm 1.85$ \\
\hline Yolk $(\%)$ & $35.61 \pm 2.85$ & $35.50 \pm 1.85$ & $35.71 \pm 2.77$ & $35.81 \pm 1.52$ \\
\hline Shell $(\%)$ & $8.81^{\mathrm{c}} \pm 0.57$ & $8.86^{\mathrm{b}} \pm 0.55$ & $8.96^{\mathrm{c}} \pm 0.57$ & $8.82^{\mathrm{b}} \pm 0.56$ \\
\hline \multicolumn{5}{|l|}{ At 16 wks of age } \\
\hline Egg weight $(\mathrm{g})$ & $10.8 \pm 0.22$ & $11.0 \pm 0.43$ & $11.3 \pm 0.18$ & $10.9 \pm 0.45$ \\
\hline Egg shape index $(\%)$ & $74.2^{\mathrm{b}} \pm 0.56$ & $77.8^{\mathrm{ab}} \pm 1.15$ & $78.6^{\mathrm{a}} \pm 1.53$ & $76.4^{\mathrm{ab}} \pm 0.76$ \\
\hline Egg yolk index $(\%)$ & $57.8 \pm 0.48$ & $58.6 \pm 1.67$ & $58.5 \pm 0.82$ & $56.9 \pm 0.49$ \\
\hline Haugh units & $88.6^{\mathrm{b}} \pm 0.59$ & $91.2^{\mathrm{a}} \pm 1.43$ & $92.8^{\mathrm{a}} \pm 1.11$ & $91.1^{\mathrm{ab}} \pm 1.51$ \\
\hline Egg shell thickness $(\mathrm{x} 0.01 \mathrm{~mm})$ & $18.5^{\mathrm{b}} \pm 0.31$ & $20.1^{\mathrm{a}} \pm 0.33$ & $20.8^{\mathrm{a}} \pm 0.42$ & $19.1^{\mathrm{b}} \pm 0.33$ \\
\hline Albumen (\%) & $55.22 \pm 2.45$ & $55.10 \pm 1.51$ & $55.11 \pm 1.51$ & $55.41 \pm 1.56$ \\
\hline Yolk $(\%)$ & $35.88 \pm 1.57$ & $35.76 \pm 1.58$ & $35.91 \pm 1.45$ & $35.88 \pm 1.05$ \\
\hline Shell (\%) & $8.88 \pm 0.72$ & $9.11 \pm 0.56$ & $9.34 \pm 0.63$ & $9.12 \pm 0.78$ \\
\hline \multicolumn{5}{|l|}{ At 20 wks of age } \\
\hline Egg weight $(\mathrm{g})$ & $11.1 \pm 0.41$ & $11.3 \pm 0.38$ & $11.6 \pm 0.15$ & $11.4 \pm 0.22$ \\
\hline Egg shape index (\%) & $76.4 \pm 1.82$ & $76.2 \pm 1.49$ & $77.6 \pm 1.74$ & $75.9 \pm 0.86$ \\
\hline Egg yolk index $(\%)$ & $60.2 \pm 2.42$ & $61.4 \pm 1.62$ & $62.5 \pm 1.82$ & $61.6 \pm 0.43$ \\
\hline Haugh units & $90.4 \pm 0.57$ & $91.6 \pm 1.33$ & $91.0 \pm 1.1$ & $90.2 \pm 0.53$ \\
\hline Egg shell thickness (x $0.01 \mathrm{~mm})$ & $19.0^{\mathrm{b}} \pm 0.34$ & $19.2^{\mathrm{ab}} \pm 0.68$ & $20.0^{\mathrm{a}} \pm 0.44$ & $19.1^{\mathrm{ab}} \pm 0.32$ \\
\hline Albumen (\%) & $54.90 \pm 1.82$ & $55.21 \pm 0.31$ & $55.01 \pm 1.82$ & $55.20 \pm 1.56$ \\
\hline Yolk $(\%)$ & $36.58 \pm 0.38$ & $35.76 \pm 1.52$ & $36.02 \pm 1.54$ & $35.81 \pm 1.82$ \\
\hline Shell $(\%)$ & $8.47 \pm 0.51$ & $9.03 \pm 0.63$ & $9.28 \pm 0.88$ & $9.08 \pm 0.55$ \\
\hline \multicolumn{5}{|l|}{ At 24 wks of age } \\
\hline Egg weight $(g)$ & $11.3 \pm 0.56$ & $11.6 \pm 0.71$ & $11.7 \pm 0.85$ & $11.5 \pm 0.66$ \\
\hline Egg shape index $(\%)$ & $76.2^{\mathrm{b}} \pm 1.24$ & $78.8^{\mathrm{ab}} \pm 1.15$ & $79.8^{\mathrm{a}} \pm 1.33$ & $78.6^{\mathrm{ab}} \pm 1.56$ \\
\hline Egg yolk index $(\%)$ & $58.6^{\mathrm{c}} \pm 1.42$ & $60.6^{\mathrm{bc}} \pm 1.65$ & $63.8^{\mathrm{a}} \pm 1.71$ & $62.6^{\mathrm{ab}} \pm 1.22$ \\
\hline Haugh units & $90.4^{\mathrm{b}} \pm 1.55$ & $90.2^{\mathrm{b}} \pm 1.42$ & $93.9^{\mathrm{a}} \pm 1.41$ & $91.2^{\mathrm{a} b} \pm 1.53$ \\
\hline Egg shell thickness (x $0.01 \mathrm{~mm})$ & $18.4^{\mathrm{b}} \pm 0.38$ & $19.1^{\mathrm{b}} \pm 0.45$ & $20.8^{\mathrm{a}} \pm 0.52$ & $19.0^{\mathrm{b}} \pm 0.61$ \\
\hline Albumen (\%) & $55.22 \pm 1.51$ & $55.30 \pm 1.57$ & $55.18 \pm 1.83$ & $55.31 \pm 1.68$ \\
\hline Yolk $(\%)$ & $36.03 \pm 1.61$ & $35.68 \pm 0.81$ & $35.91 \pm 1.31$ & $35.71 \pm 1.41$ \\
\hline Shell $(\%)$ & $8.65 \pm 0.58$ & $9.01 \pm 0.53$ & $9.18 \pm 0.23$ & $8.97 \pm 0.51$ \\
\hline
\end{tabular}

a, b, c and d Means within each row for each division (C,T1, T2 and T3) with no common superscripts are significantly different $(\mathrm{P} \leq 0.05)$.

$\mathrm{C}=\mathrm{Control}$ group (birds were fed at 0900 and $1500 \mathrm{~h}$ )

$\mathrm{T} 1=$ Treatment group (birds were fed at 1500 and $2100 \mathrm{~h}$ )

$\mathrm{T} 2=$ Treatment group (birds were fed at 2100 and $0300 \mathrm{~h}$ )

$\mathrm{T} 3=$ Treatment group (birds were fed at 0300 and $0900 \mathrm{~h}$ ) 


\section{Table 7: Means $\pm \mathrm{SE}$ of fertility and hatchability in Japanese quail as affected by feeding time.}

\begin{tabular}{|c|c|c|c|c|c|c|c|c|}
\hline \multirow{2}{*}{$\begin{array}{c}\text { Age } \\
(\mathrm{wks})\end{array}$} & \multicolumn{5}{|c|}{ Fertility (\%) } & \multicolumn{4}{c|}{ Hatchability (\%) } \\
\cline { 2 - 9 } & $\mathrm{C}$ & $\mathrm{T} 1$ & $\mathrm{~T} 2$ & $\mathrm{~T} 3$ & $\mathrm{C}$ & $\mathrm{T} 1$ & $\mathrm{~T} 2$ & $\mathrm{~T} 3$ \\
\hline 12 & $80.5^{\mathrm{b}} \pm 2.53$ & $84.8^{\mathrm{b}} \pm 5.31$ & $91.7^{\mathrm{a}} \pm 2.63$ & $81.8^{\mathrm{b}} \pm 4.51$ & $60.3^{\mathrm{c}} \pm 2.53$ & $63.6^{\mathrm{ab}} \pm 2.31$ & $65.9^{\mathrm{a}} \pm 3.72$ & $62.9^{\mathrm{b}} \pm 5.81$ \\
\hline 16 & $82.1^{\mathrm{b}} \pm 3.58$ & $87.7^{\mathrm{ab}} \pm 3.85$ & $92.4^{\mathrm{a}} \pm 3.52$ & $86.8^{\mathrm{ab}} \pm 5.81$ & $53.8^{\mathrm{c}} \pm 4.55$ & $63.8^{\mathrm{b}} \pm 6.56$ & $70.7^{\mathrm{a}} \pm 2.89$ & $64.3^{\mathrm{b}} \pm 3.37$ \\
\hline 20 & $83.3^{\mathrm{b}} \pm 5.36$ & $89.8^{\mathrm{ab}} \pm 2.75$ & $94.9^{\mathrm{a}} \pm 4.63$ & $88.3^{\mathrm{ab}} \pm 4.52$ & $58.5^{\mathrm{c}} \pm 5.71$ & $63.5^{\mathrm{b}} \pm 4.72$ & $66.4^{\mathrm{a}} \pm 1.65$ & $62.2^{\mathrm{ab}} \pm 4.58$ \\
\hline 24 & $81.3^{\mathrm{b}} \pm 6.73$ & $86.6^{\mathrm{ab}} \pm 5.52$ & $93.6^{\mathrm{a}} \pm 2.59$ & $89.6^{\mathrm{ab}} \pm 5.65$ & $48.9^{\mathrm{b}} \pm 3.32$ & $59.7^{\mathrm{ab}} \pm 3.91$ & $61.8^{\mathrm{a}} \pm 0.98$ & $58 .{ }^{\mathrm{b}} \pm 2.63$ \\
\hline $\begin{array}{c}\text { Overall } \\
\text { mean }\end{array}$ & $81.8^{\mathrm{b}} \pm 4.88$ & $87.2^{\mathrm{ab}} \pm 4.52$ & $93.2^{\mathrm{a}} \pm 3.66$ & $86.6^{\mathrm{ab}} \pm 5.75$ & $55.4^{\mathrm{c}} \pm 4.52$ & $62.7^{\mathrm{b}} \pm 5.58$ & $66.2^{\mathrm{a}} \pm 2.81$ & $61.9^{\mathrm{b}} \pm 3.72$ \\
\hline
\end{tabular}
significantly different $(\mathrm{P} \leq 0.05)$.

$\mathrm{C}=\mathrm{Control}$ group $($ birds were fed at 0900 and $1500 \mathrm{~h}$ )

$\mathrm{T} 1=$ Treatment group (birds were fed at 1500 and $2100 \mathrm{~h}$ )

$\mathrm{T} 2=$ Treatment group (birds were fed at 2100 and $0300 \mathrm{~h}$ )

$\mathrm{T} 3=$ Treatment group (birds were fed at 0300 and $0900 \mathrm{~h}$ )

Table 8: Economical efficiency for growing and laying Japanese quail as affected by feeding time.

\begin{tabular}{|c|c|c|c|c|c|}
\hline \multicolumn{2}{|r|}{ Items } & \multicolumn{4}{|c|}{ Treatment } \\
\hline & & $\mathrm{C}$ & $\mathrm{T} 1$ & $\mathrm{~T} 2$ & T3 \\
\hline \multicolumn{6}{|l|}{ Growing period: } \\
\hline \multirow{3}{*}{ Total costs/ bird/L.E } & Price of chick at one day of age (L.E) & 0.5 & 0.5 & 0.5 & 0.5 \\
\hline & Total feed consumption $(\mathrm{kg} / \mathrm{bird})$ & 0.70 & 0.71 & 0.70 & 0.73 \\
\hline & Total feed costs (L.E) & 1.28 & 1.30 & 1.28 & 1.34 \\
\hline $\begin{array}{l}\text { Total revenue/ } \\
\text { bird/L.E }\end{array}$ & Selling price of bird at 8 weeks of age (L.E) & 2.97 & 3.28 & 3.43 & 3.11 \\
\hline \multicolumn{2}{|c|}{ Net revenue/ bird/L.E (without *constant costs $=25 \%$ ) } & 1.19 & 1.48 & 1.64 & 1.27 \\
\hline \multicolumn{2}{|c|}{ Economical efficiency/bird (EE) } & 0.93 & 1.14 & 1.28 & 0.94 \\
\hline \multicolumn{2}{|c|}{ Relative economical efficiency/bird (REE) } & 100.0 & 122.6 & 137.9 & 101.6 \\
\hline \multicolumn{6}{|l|}{ Laying period: } \\
\hline \multirow{3}{*}{ Total costs/ bird/L.E } & Price of chick at 8 weeks of age (L.E) & 2.97 & 3.28 & 3.43 & 3.11 \\
\hline & Total feed consumption (kg/bird) & 2.10 & 2.11 & 2.02 & 2.16 \\
\hline & Total feed costs (L.E) & 3.86 & 3.88 & 3.72 & 3.98 \\
\hline \multirow{3}{*}{$\begin{array}{l}\text { Total revenue/ } \\
\text { bird/L.E }\end{array}$} & $\begin{array}{l}\text { Selling price of bird at } 24 \text { weeks of age } \\
\text { (L.E) }\end{array}$ & 3.23 & 3.37 & 3.52 & 3.34 \\
\hline & Fertile egg number/hen & 81.8 & 87.2 & 93.2 & 86.6 \\
\hline & Selling price for fertile eggs/hen/L.E & 12.62 & 15.77 & 18.44 & 14.60 \\
\hline \multicolumn{2}{|c|}{ Net revenue/ bird/L.E (without *constant costs=25\%) } & 9.02 & 11.98 & 14.81 & 10.85 \\
\hline \multicolumn{2}{|c|}{ Economical efficiency/bird (EE) } & 2.34 & 3.09 & 3.98 & 2.73 \\
\hline \multicolumn{2}{|c|}{ Relative economical efficiency/bird (REE) } & 100.0 & 132.0 & 170.3 & 116.7 \\
\hline
\end{tabular}

Cost of $1 \mathrm{~kg}$ of live body weight $=16.00 \mathrm{~L}$.E.

Price of 1 fertile egg $=0.25$ L.E.

Price of $1 \mathrm{~kg}$ litter $=0.04$ L.E.

Price of $1 \mathrm{~kg}$ manure $=0.05$ L.E.

Price of $1 \mathrm{~kg}$ of growing ration $=1.84 \mathrm{~L} . \mathrm{E}$.

L.E = Egyptian pound.

Price of $1 \mathrm{~kg}$ of laying ration $=1.68 \mathrm{~L} . \mathrm{E}$.

EE/bird=Net revenue per unit of total costs

$\mathrm{a}, \mathrm{b}, \mathrm{c}$ and d Means within each row for each division (C,T1, T2 and T3) with no common superscripts are significantly different $(\mathrm{P} \leq 0.05)$.

$\mathrm{C}=\mathrm{Control}$ group (birds were fed at 0900 and $1500 \mathrm{~h}$ )

$\mathrm{T} 1=$ Treatment group (birds were fed at 1500 and $2100 \mathrm{~h}$ )

$\mathrm{T} 2=$ Treatment group (birds were fed at 2100 and $0300 \mathrm{~h}$ )

$\mathrm{T} 3=$ Treatment group (birds were fed at 0300 and $0900 \mathrm{~h}$ )

*Constant costs include: housing, labour, heating, cooling, lighting and treatment regimens. 


\section{REFERENCES}

Abd El-Hakim, A.S. and Abd-Elsamee, M.O. (2003): Effect of feeding systems and phytase supplementation on the performance of broiler chicks during summer season. Egypt. Poult. Sci. J., 24: 297-310.

Aengwanich, W. (2007a): Effects of High Environmental Temperature on the Productive Performance of Thai Indigenous, Thai Indigenous Crossbred and Broiler Chickens. International J. of Poult. Sci., 6: 349-353.

Aengwanich, W. (2007b): Effects of High Environmental Temperature on Blood Indices of Thai Indigenous Chickens, Thai Indigenous Chickens Crossbred and Broilers. International J. of Poult. Sci., 6: 427-430.

Avila, V.; Penz, J.A.; Brum, P.; Rosa P.; Guidoni, A. and Figueiredo, E. (2003a): Performance of female broiler breeders submitted to different feeding schedules. Rev. Bras. Cienc. Avic., 6:5.

Avila, V.; Penz, J.A.; Rosa, P.; Brum P.; Guidoni, A. and Ledur, M. (2003b): Influence of feeding time on sexual maturity and carcass composition in female broiler breeders. Rev. Bras. Cienc. Avic., 5:3.

Balnave, D. (1977): The effect of energy restriction on laying hens given either a single morning or single evening meal. Br. Poult. Sci., 18: 115-119.

Bootwalla, S.; Willson, H.R. and Harms, R.H. (1983): Performance of broiler breeders on different feeding systems. Poult. Sci., 62: 2321-2325.

Bouvarel, I.; Guillot, B.; Larroude, P.; Boutten, B.; Leterrier, C.; Merlet, F.; Vilarino, M.; Roffidal, L.; Tesseraud, S.; Castaing, J. and Picard, M. (2004): Sequential feeding programs for broiler chickens twenty-four- and forty-eight-hour cycles. Poult. Sci., 83: 49-60.

Brake, J.D. (1988): Relationship of time and strain to egg shell quality and hatchability in broiler breeders. Poult. Sci., 67: 538-543.

Brake, J.D. and Peebles, E.D. (1986): Effects of strain and time of feeding on reproductive performance and shell quality of broiler breeders. Poult. Sci., 65 (Suppl. 1):156. (Abstr.).

Brant, A.W. and Shrader, H.L. (1952): How to measure internal egg quality? Bureau of Animal Industry. Agric. Res. Administration, U.S. Dept. of Agric., Circular P. A. 202. 
Cave, NA. (1981): Effect of diurnal programs of nutrient intake on performance of broiler breeder hens. Poult. Sci., 60: 1287-1292.

Carmen, A.F.; Macleod, M.G. and Anderson, E.M. (1995): Alleviation of a cute heat stress by food withdrawal or darkness. Br. Poult. Sci., 32: 219-225.

Duncan, D.B. (1955): Multiple range and multiple F test. Biometrics 11: $1-42$.

Duncan, J.H. and Hughes, B.O. (1975): Feeding activity and egg formation in hens laid continuously. Br. Poult. Sci., 16: $145-155$.

Emara, M.E.M. (1982): Effect of crossbreeding on some productive traits in rabbits. Ph.D. Thesis, Fac. of Agric. Sci., Moushtohor, Zagazig Univ., Egypt.

Farghly, M.F.A. (2008): Improvement of poultry production through some recent managerial manipulations in Assiut. Ph.D. thesis, Fac, of Agric. Assiut Univ., Egypt.

Farmer, M.; Roland, D.A. and Eckman, M.K. (1983): Calcium metabolism in broiler breeder hens. 2. The influence of the time of feeding on calcium status of the digestive system and egg shell quality in broiler breeders. Poult. Sci., 62: 465-471.

Geraet, P.A.; Padilha, J.C.F. and Guillaumim, S. (1996): Metabolic and endocrine changes induced by chronic heat exposure in broiler chickens: growth performance, body weight and energy retention. Br. J. Nutr. 75: 195-204.

Harms, RH. (1991): The influence of changing time of feeding on performance of broiler breeder hens. Poult. Sci., 70: 1695-1698.

Hassan, S.M.; Mady, M.E.; Cartwright, A.L.; Sabri, H.M. and Mobarak, M.S. (2003): Effect of early feed restriction on reproductive performance in Japanese quail (Coturnix coturnix japonica). Egypt. Poult. Sci. J., 23: 1163-1169.

Keshavarz, K. (1998): Investigation on the possibility of reducing protein, phosphorus, and calcium requirements of laying hens by manipulation of time of access to these nutrients. Poult. Sci., 77: 1320-1332.

Koh, K.; Karasawa, Y. and Sekigawa, K. (2000): Effects of feeding on body temperature, heart rate and shivering threshold in growing broilers acutely exposed to the cold. Faculty of Agric., Shinshu Univ., Minamiminowa, Nagano 399-4598, Japan. Poult. Sci.. 37: $12-18$. 
Kohne, H.J.; Boone, M.A. and Jones, E. (1973): The effect of feed consumption on the survival time of adult turkey hens under conditions of acute thermal stress. Poult. Sci., 52: 1780-1783.

Kondaiah, N.; Panda, B. and Singhal, R.A. (1983): Internal quality measures for quail eggs. Indian J. of Anim. Sci., 53: 1261-1264.

Leeson, S.A. (1992): Feeding programs for broiler breeder hens a major challenge. Better hen performance is achieved when body weight gain is optimum through the later transition period. Poult. Digest. 51: 24-41.

Leeson, S.A. and Summers, J.D. (2000): Broiler breeder production. univ. Books, Guelph, Ontario, Canada, N1H6N8.

Lennards, R.; Roland, D.A.S. and McGuire, J.A. (1981): The relationship of serum calcium to shell weight and other criteria in hens laying a low or high incidence of shell-less eggs. Poult. Sci., 60: 2501- 2505.

Marai, I.F.M.; Askar, A.A. and Bahgat, L.B. (2006): Tolerance of New Zealand White and Californian doe rabbits at first parity to the sub-tropical environment of Egypt Livestock Science 104 (2006) 165-172.

Marai, I.F.M.; Habeeb, A.A.M. and Gad, A.E. (2002): Rabbits productive, reproductive and physiological performance traits as affected by heat stress: a review. Livest. Prod. Sci. 78: 71-90.

Marai, I.F.M.; Ayyat, M.S.; Gabr, H.A. and Abd El-Monem, U.M. (1996): Effect of heat stress and its amelioration on production performance of New Zealand White adult female and male rabbits, under Egyptian Conditions. In: Proceedings of $6^{\text {th }}$ World Rabbits Congress, Toulouse, France, 2, pp, 197-202.

McDaniel, G.R.; Roland, D.A. and Coleman, M.A. (1979): The effect of egg shell quality on hatchability and embryonic mortality. Poult. Sci., 58: 10-13.

National Research Council, (1994): Nutrient Requirements of Poultry.9th rev.ed. National Academy Press, Washington,D.C.

North, M.O. (1978): Commercial chicken production manual. Second Ed. Avi Publishing Co., Inc., West port, Ct.

Reddy, P.M.; Reddy, V.R.; Reddy, C.V. and Rap, P.S.P. (1979): Egg weight, shape index and hatchability in Khaki Campbell duck egg. Ind. J. Poult. Sci., 14: 26-31. 
Roland, D.A.; Sloan, D.R. and Harms, R.H. (1972): Calcium metabolism in the laying hen. 3. Pattern of feed (calcium) intake as influenced by time of day and oviposition. Poult. Sci., 51: 1388-1391.

Saiful, I.M.; Fujita, M. and Ito, T. (2002): Effect of feeding levels and physical activities on heat production in laying hens under different ambient temperatures. Poul. Sci. 39: 118-125.

Samara, M.H.; Robbins, K.R. and Smith, M.O. (1996): Interaction of feeding time and temperature and their relationship to performance of the broiler breeder hen. Poult. Sci., 75: 34-41.

SAS (1996): SAS User's Guide, statistics $\left(6.2^{\text {th }}\right.$ ed.)Cary NC: SAS Institute Inc.

Teeter, R.G.; Smith, M.O.; Sandiah, S. and Mather, F.B. (1987): Effects of feed intake and fasting duration upon body temperature and survival of thermostressed broilersNutrition Report International, 35: 531-537.

Veltmann, J.R.; Gardner, JR. F.A and Linton, S.S. (1984): Comparison of rice hull products as litter material and dietary fat levels on turkey poult performance. Poult. Sci., 63: 2345-2351.

Wiernusz, V.J. and Teeter, R.G. (1993): Feeding effects on broiler thermobalance during thermoneutral and high ambient temperature exposure. Poult. Sci., 72: 1917-1924.

Wilson, H.R.; Mather, F.B.; Brigmon, R.L.; Besch, E.L.; Dugan, V.P. and Boulus, N.Z. (1989): Feeding time and temperature interactions in broiler breeders. Poult. Sci., 68: 608-616.

Wilson, H.R. and Keeling, L.J. (1991): Effect of time of feeding oviposition on time and production parameters in broiler breeders. Poult. Sci., 70: 254-259.

Yahav, S.; Straschnow, A.; Plavnk, I. and Hurwitz, S. (1995): Effects of diurnally cycling versus constant temperature on chicken growth and food intake. Br. Poult. Sci., 37: pp. 43-54.

Yahav, S.; Rath, R.S. and Shinder, D. (2004): The effect of thermal manipulations during embryogenesis of broiler chicks (Gallus domesticus) on hatchability, body weight and thermoregulation after hatch. J. of Thermal Biology. 29 (4-5):

Zubair, A.K. and Leeson, S. (1994): Effect of early feed restriction and realimentation on heat production and changes in size of digestive organs of male broilers. Poult. Sci. 73: 529-538. 